Rapp. Grønlands geol. Unders. 48, 39-59 (1972)

\title{
FIELD OBSERVATIONS IN PALAEOZOIC AND MESOZOIC SEDIMENTS OF SCORESBY LAND AND NORTHERN JAMESON LAND
}

\author{
K. Perch-Nielsen, R. G. Bromley, K. Birkenmajer and M. Aellen
}

\section{Introduction}

The 1971 summer season was the last within GGU's five year mapping programme in the Scoresby Sund region to involve Scoresby Land and Jameson Land. The field work in the northern part of this area was carried out by four parties (see fig. 5). M. Aellen (Zürich) revisited the area of Gurreholm Bjerge, mapped by him in 1957 and 1958. He was assisted by S. Stouge (Copenhagen) who collected material for studies on Permian conodonts. R. G. Bromley and U. Asgaard (Copenhagen) revised Callomon's (1970) map along the southern part of Carlsberg Fjord and northern Klitdal and visited areas east and south-east of Schuchert Flod. K. Birkenmajer (Kraków) spent part of the season in Gipsdalen and Pingo Dal, Klitdal and Wegener Halvø for sedimentological studies in the Triassic. He was assisted by B. Buchardt Larsen (Copenhagen) who made special studies of the gypsiferous layers of the Triassic. K. Perch-Nielsen (Copenhagen) was assisted by S. Priisholm (Århus) and mapped around Kap Biot, on Wegener Halvø and along Carlsberg Fjord, mainly revising the maps of Grasmück \& Trümpy (1969) and Callomon (1970). A preliminary geological map of the southern part of the Jameson Land is to be published by Surlyk et al. (this report). For the northern part of the area, a preliminary geological map has been published by Bromley et al. (1970). The present report contains the principal results of the field work in 1971 together with observations made by M. Aellen in 1957 and 1958. S. E. BendixAlmgreen (Copenhagen) kindly identified the vertebrate remains.

\section{Precambrian}

The Precambrian Eleonore Bay Group occurs on Wegener Halvø at Kap Brown and north and south of Trekegledal in a thin belt along Fleming Fjord (R. Caby, this report). At the last locality it consists of quartzites and green and black hard 


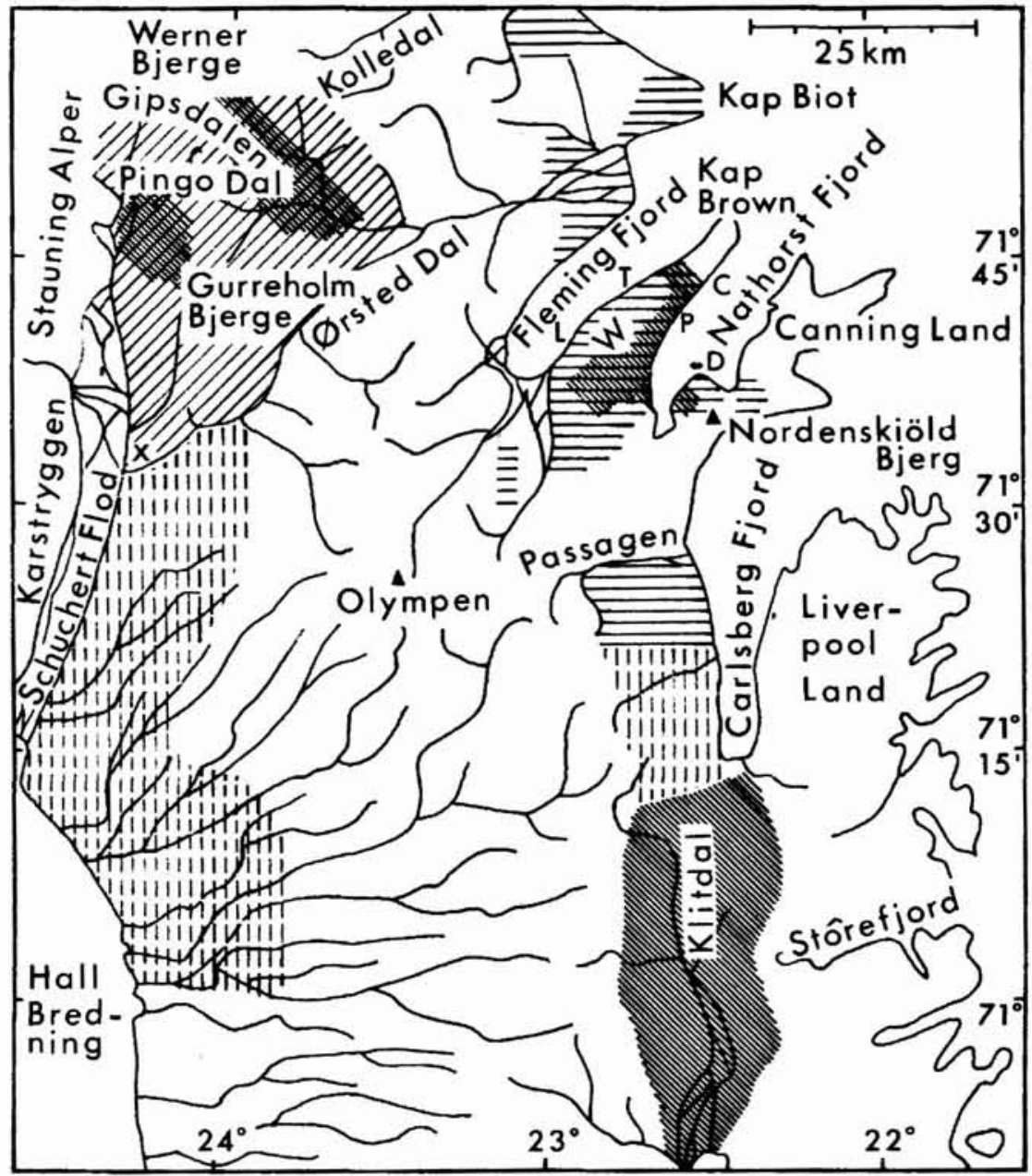

A reas mapped by:

M. Aellen

K. Birkenmajer
K. Perch-Nielsen

iiiiiii R. Bromley and U. Asgaard

Fig. 5. Map of southern Scoresby Land and northern Jameson Land showing working areas and localities mentioned in the text. X: locality shown in fig. 8. W: Wegener Halvø.

T: Tvekegledal. L: Lagunenæsdal. C: Calamitesdal. P: Paradigmabjerg. D: Depot $\emptyset$.

shales with only thin calcareous intercalations. The contact with the overlying Devonian sediments is tectonic. 


\section{Palaeozoic}

\section{Devonian}

\section{Kap Fletcher volcanics}

On Wegener Halvø, the Devonian Kap Fletcher volcanics are found to the south of Kap Brown and north and south of Tvekegledal in connection with the Eleonore Bay Group. Green and violet-red porphyric rhyolites occur in outcrops, and as boulders in younger Devonian conglomerates (Wegener Halvø) and Triassic conglomerates and arkoses (Klitdal and Nordenskiöld Bjerg).

\section{Sediments}

Devonian conglomerates, arkoses, sandstones and silty shales underlie the marine Upper Permian with an angular unconformity on Wegener Halvø, west of the graben through the central part of the peninsula. They are the youngest rocks east of this graben. No Devonian rocks were found in the central graben on Wegener Halvø or on the western side of the East Greenland basin at this latitude.

\section{Carboniferous and Lower Permian}

The exposed Carboniferous to Lower Permian deposits on the west side of the basin are confined to the wide fault zone dividing the uplifted crystalline complex of the Stauning Alper in the west from the down-thrown Mesozoic sediments of the basin to the east.

The Carboniferous and Permian succession is more than $2000 \mathrm{~m}$ thick and is almost entirely composed of clastic, predominantly arkosic, sediments (table 1). Earlier investigations in different parts of the distribution area, including the Mesters Vig region (Bierther, 1941; Witzig, 1954), parts of Werner Bjerge (Bromley et al., 1970) and Schuchert Dal (Kempter, 1961; Aellen, manuscript in prep.), produced different schemes for the stratigraphical subdivision of the sequence. We suggest that Witzig's scheme for the Mesters Vig region, with the names proposed by Kempter (1961, p. 108), be tentatively applied to the whole area between Kong Oscars Fjord and Scoresby Sund. The whole sequence then is referred to the Mesters Vig Formation which comprises the following lithostratigraphical units, from bottom to top (descriptions referring mainly to the succession found in southern Scoresby Land).

Skeldal Member: green, friable arkoses containing red feldspar, alternating with silty and carbonaceous layers with fish remains. This unit is exposed only in Skeldal and was considered by Bierther (1941) to be the oldest part of the Carboniferous sequence exposed south of Kong Oscars Fjord. 
Table 1. Distribution, approximate age and lithological subdivision of Carboniferous and Permian sediments in northern Jameson Land and Scoresby Land

For symbols see table 3 .

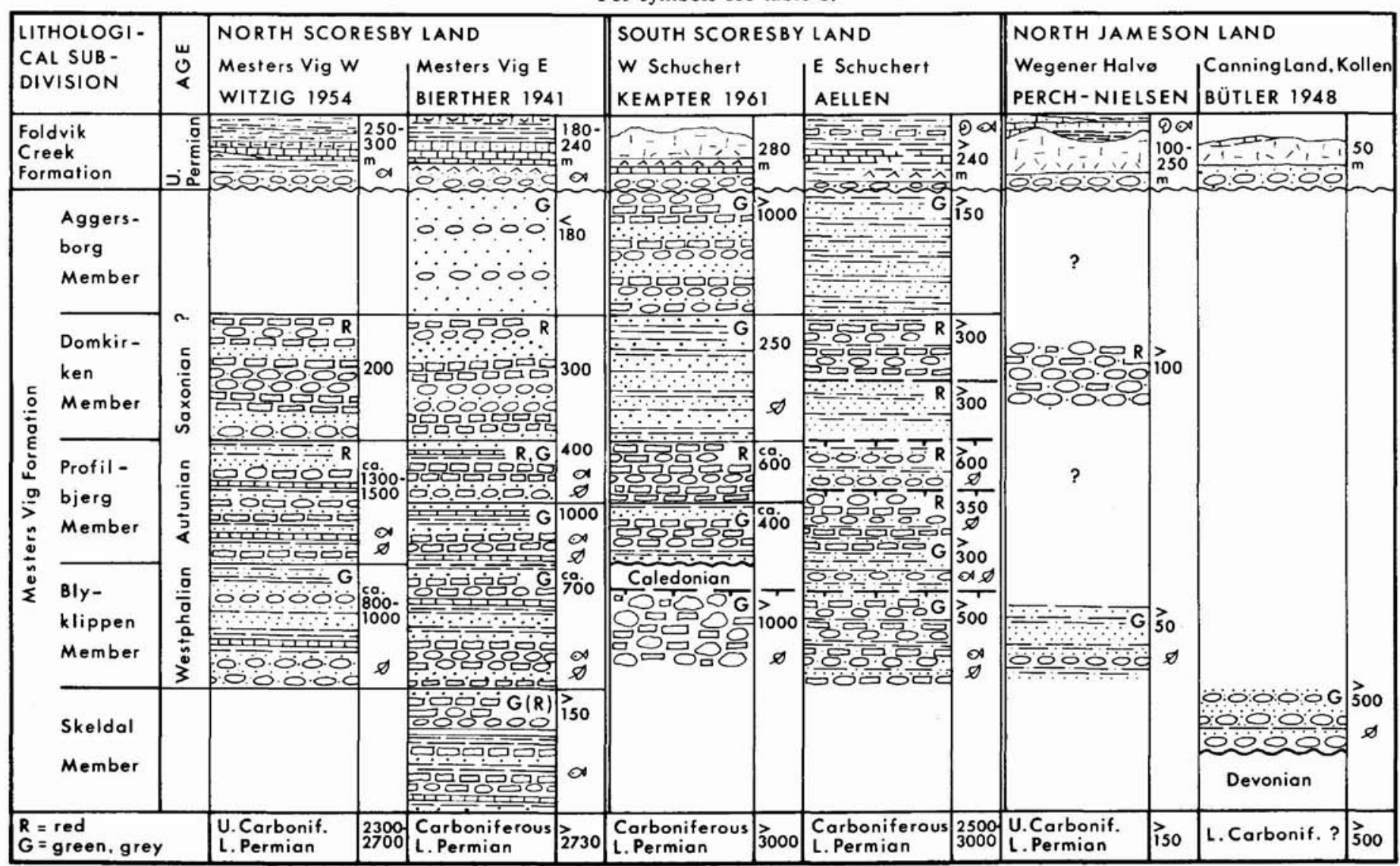


Blyklippen Member: light-coloured, white to brown-grey conglomerates, breccias and sandstones, with a typical absence of red feldspar grains and red granite pebbles, intercalated with dark grey to black siltstones, and silty and carbonaceous shales containing plant and fish remains of an Upper Carboniferous (Westphalian) age. These occur in the valleys around Mesters Vig and in the northern part of Schuchert Dal, where they are exposed on the west slope, in the flood-plain and in the lowermost part of the east slope. Conglomerates and arkoses are considerably less coarse in the upper part of the north-west slope and east of Schuchert Dal, indicating a western source area and reduction of relief with time.

Profilbjerg Member: this consists of well bedded, platy, green, grey, pink to purplish or brown arkoses, mainly coarse sandstones or microbreccias and siltstones with red feldspar grains and thin conglomeratic layers. These alternate with pelitic intercalations containing plant and fish remains, concretions, flow marks, slump structures etc. The member is widely distributed in the Mesters Vig region and in the Karstryggen area west of Schuchert Flod. A Lower Permian age has been suggested for the upper part of the unit on the basis of palynological evidence. East of Schuchert Flod, where this type of arkose comprises the west slope of Gurreholm Bjerge, the unit has been cut through diagonally by the Zechstein transgression so that it is overlain unconformably by the Upper Permian Foldvik Creek Formation.

Domkirken Member: this comprises pink to purplish red conglomerates and sandy arkoses with (commonly) red granite pebbles, interbedded with finer-grained psammites and silty layers. This member forms the top of the Carboniferous-Lower Permian sequence in the central part of the Mesters Vig region and at the head of Pingo Dal, owing to the erosion in Permian time of the overlying Aggersborg Member. In the Karstryggen area coarse conglomerates and breccias of a similar type are considered to be equivalents of the Lower Permian local units which have been correlated with the Profilbjerg Member (Kempter, 1961). No fossils are known from these arkosic red beds which Witzig (1954) has compared to the New Red Sandstone.

Aggersborg Member: grey arkosic sandstones and siltstones with intercalations of silty and carbonaceous shales, overlying the Domkirken Member and overlain unconformably by the Foldvik Creek Formation, are found east and south-east of Mesters Vig bay and in the south-western corner of Werner Bjerge. These too, were deposited before faulting and very slight folding which was followed by peneplanation and the transgression of the Zechstein sea.

The proposed stratigraphical system is based on the most obvious and most general lithological features and gives only a very rough correlation of gross units with- 
out sharp boundaries. More detailed divisions have been proposed by Bierther (1941, and in prep.) for the northern part, and by Kempter (1961) and Aellen (manuscript in prep.) for the southern part of Scoresby Land. However, owing to the frequent lateral and vertical changes in lithology, to the lack of sufficient palaeontological evidence and other time-stratigraphical zonation, and also to the rather obscure fault tectonics, their correlation is considered premature speculation.

On the east side of the basin continental Carboniferous and Lower Permian molasse-like sediments occur in the down-faulted graben on Wegener Halvø and on Canning Land. In contrast to previous investigations (Noe-Nygaard, 1934; Grasmück \& Trümpy, 1969) it was found that two different lithologies can be distinguished for the Carboniferous to Lower Permian deposits on Wegener Halvø. The outcrops in the lower part of Calamitesdal and along the main fault in Tvekegledal consist of light grey or greenish sandstones, black shales and only minor conglomeratic intercalations. Plant remains from thin coal seams have been considered as of Namurian to Lower Westphalian age (Grasmück \& Trümpy, 1969). The "Carboniferous" outcrops along Fleming Fjord north-east of Tvekegledal and along Nathorst Fjord south of Paradigmabjerg, and higher up in Calamitesdal, consist of dark red conglomerates and arkoses and have not furnished any fossils. They can tentatively be correlated with the Domkirken Member (Witzig, 1954) of the western part of the basin, which is considered to be Lower Permian in age on the basis of pollen and spores found in the slightly older or contemporaneous Ødemarksdal Member (Kempter, 1961, p. 35).

\section{Upper Permian}

The marine Upper Permian Foldvik Creek Formation also crops out on both sides of the basin (fig. 6). To the east, on Wegener Halvø and the south-western part of Canning Land, it overlies Devonian, and Carboniferous to Lower Permian deposits with an angular unconformity. Over most of this area a reddish, coarse

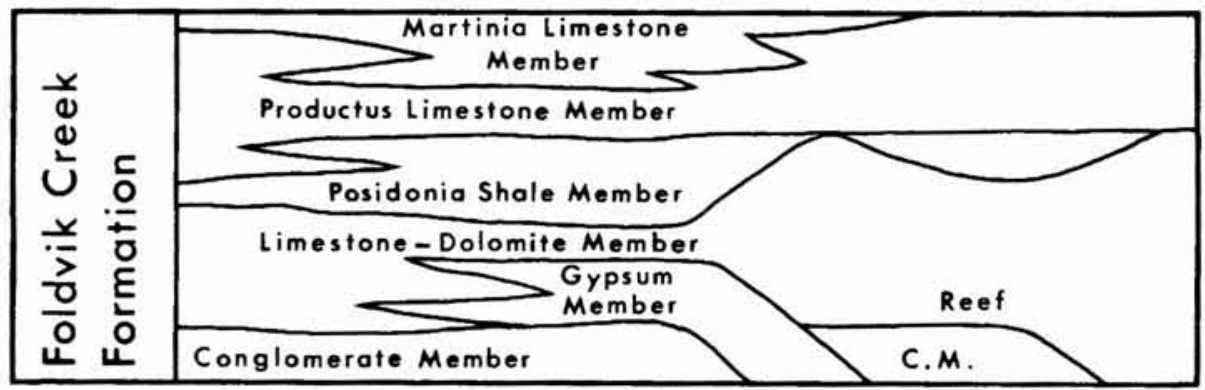

Fig. 6. Simplified scheme of the Upper Permain Foldvik Creek Formation and its members. Members as in Maync (1942). 
conglomerate to breccia forms the base of the formation (Conglomerate Member of Maync, 1942). It varies in thickness from 0 to $50 \mathrm{~m}$. Generally, the overlying recifal limestones of the Limestone-Dolomite Member are underlain by breccious limestones and dolomites often covered by scree. The fossil content of the reef that forms steep cliffs is variable and is usually greatest in its uppermost part. The maximum thickness of these limestones diminishes from over $100 \mathrm{~m}$ in the east to about $15 \mathrm{~m}$ in the westernmost outcrops on Wegener Halvø, towards the central part of the basin. Benches of fossil-rich, sometimes arenaceous limestones often overlie the reef. Black to grey, silty and sometimes bituminous shales (Posidonia Shale Member of Maync, 1942) fill small basins between high parts of the reefs (fig. 7). Large yellow-weathering concretions in the shales occasionally contain fish

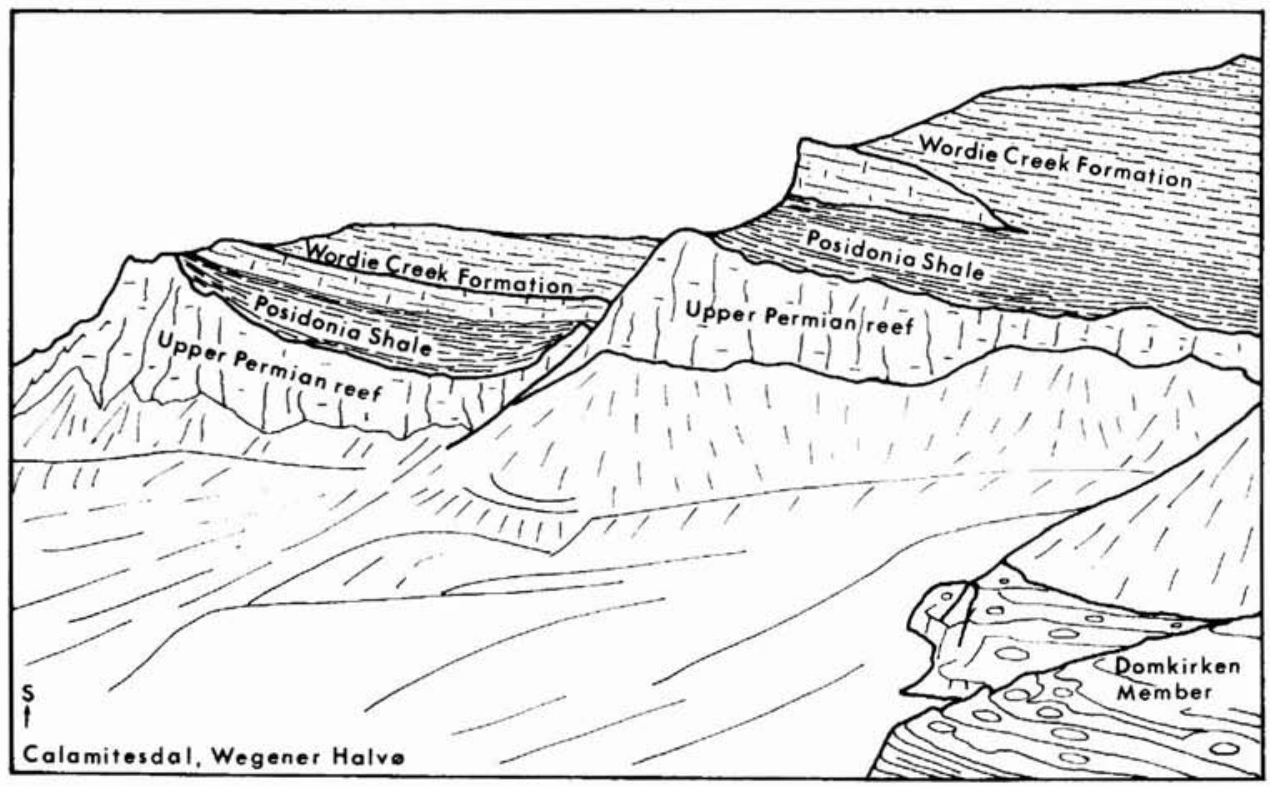

Fig. 7. Posidonia Shales filling basins in reefs (Upper Permian) south of Calamitesdal, Wegener Halvø. From a photograph.

remains. The limestones overlying or interfingering with the Posidonia Shale Member contain varying amounts of sand and even small, mostly well rounded quartzite pebbles; their fossil content also varies both quantitatively and qualitatively and they can tentatively be assigned to the Productus Limestone and Martinia Limestone Members.

Common fossil groups represented in the marine Upper Permian are brachiopods, crinoids, bryozoans and pelecypods; gastropods, corals and foraminifera are occasionally found, while belemnites were found only at one locality near Lagunenæsdal, from where Grasmück \& Trümpy (1969) also 
reported a questionable Cyclolobus. Fish remains from the Posidonia Shale include two acrolepids: Plegmolepis sp. and cf. Acropholis. A spine of an elasmobranch (new type for the Permian of Greenland) and fragments of reptile bones were also found, the latter in the Productus Limestone.

- In the western part of the basin the marine Upper Permian sequence is also confined to the marginal fault zone. West of Schuchert Flod the reefy facies of the Limestone-Dolomite Member is predominant, building up the table mountains of the Karstryggen massiv. Interfingering with the reef are complexes of the stratified facies of the same member, or evaporite bodies of the Gypsum Member. Maync's (1942) stratigraphical subdivision of the Upper Permian north of $74^{\circ} \mathrm{N}$ can therefore be used also for the area south of this parallel. On the east slope of Schuchert Dal and in southern Werner Bjerge most lithotypes except the reefy facies have been identified. In contrast to Kempter's (1961) interpretation, they are not interchangeable in any possible combination. The basal Conglomerate Member and overlying Limestone-Dolomite and/or Gypsum Member, grading up into the Posidonia Shale Member, together compose the lower part of the Foldvik Creek Formation $c .120$ to $150 \mathrm{~m}$ thick. In the field this sequence is easily recognisable as steep prominent cliffs with characteristic colour bands which contrast with the underlying continental Palaeozoic sediments. The upper part of about the same thickness is characterised by interbedding of psammitic and pelitic layers and forms gentle slopes covered with scree. In this part the Martinia and Productus Limestone Members are the most important units.

The basal conglomerate, deposited on a rather smooth peneplain, is developed in typical facies with abundant red granite boulders and pebbles which are considerably coarser than those in the underlying continental beds. Very sharp stratigraphical boundaries and a very regular shape are characteristics of this unit. Its thickness gradually increases from $15 \mathrm{~m}$ in the south to $c .30 \mathrm{~m}$ in the north. Locally thicknesses of more than $50 \mathrm{~m}$ have been observed where canyon-like structures in the Permian peneplain have been filled. Here the filling-in basal part of the member has a much coarser texture and often contains boulders up to $3 \mathrm{~m}$ in diameter derived from the underlying beds.

The Limestone-Dolomite Member is represented by banked, often sandy, breccious or pseudo-oolitic and dolomitic limestones with brachiopods, anthozoans, bryozoans, foraminifera, etc. It is replaced laterally by the unfossiliferous Gypsum Member. The gypsum is present in various forms such as large white lenses, pebble-like nodules of many sizes in silty or sandy matrix, as matrix and veins in brecciated silty shales or marls, and as massive banks of alabaster.

The Limestone-Dolomite Member grades upwards into the Posidonia Shale Member which was deposited under euxinic conditions. It consists mainly of dark bituminous or calcareous shales containing the probably pseudo-planktonic pelecypod Posidonia permica Newell as the only fossil. The frequent concretionary or thinly banked intercalations of black limestone contain a relatively rich nectonic 
fauna with belemnites, small gastropods and fishes. Thus a transgressive development in the sedimentation area is indicated by the lithostratigraphical units of the older part of the Foldvik Creek Formation. Chemical sedimentation diminished in the upper part where slabby light brown arkosic sandstones containing few body fossils but often abundant traces of a mud-eating infauna are interbedded with light grey weathering, of ten greenish or bluish pyritiferous micaceous siltstones and marls containing mainly brachiopods and bryozoans. Maync's (1942) scheme is not applicable to this part of the formation without certain reservations regarding the lithological characterisation. This is particularly the case with the sandy members in Scoresby Land which do not show any typical features of red beds and for which, therefore, the term "Red Bed Member" is unsuitable. It would be preferable to refer to this unit as the "Sandstone Member".

The Upper Permian age of the succession is revealed by the overlying fossiliferous silty layers. These do not correspond exactly in lithology to the typical Martinia Limestone Member and Productus Limestone Member of the northern area, but to the silty and marly intercalations common in the lower part and even predominant in the upper part of the Martinia Limestone Member as described by Maync (1942). With respect to the biofacies there is no doubt that both the Martinia Limestone and the Productus Limestone Members are present in south Scoresby Land in the same silty lithofacies. Where the Permian/Triassic boundary is exposed, Martinia-bearing siltstones are the highest fossiliferous and identifiable unit of the Foldvik Creek Formation. In the southernmost outcrops these layers contain fairly well preserved, partly pyritized specimens of Cyclolobus kullingi (Frebold), the index fossil of the youngest fossil zone of the (marine) Palaeozoic.

Sampling for conodonts was concentrated in the western part of the basin. Material was collected from the Posidonia Shale Member and the Martinia Limestone Member in sandy and silty facies. Results so far show that most samples yielded conodonts. The following elements are represented: Gondolella sp., $\mathrm{Oz}$ arkodima sp., Lonchodima sp. and unidentified specimens possibly belonging to Hindeodella. All these genera are already known from the Upper Permian at Kap Stosch, $74^{\circ} 03^{\prime} \mathrm{N}, 21^{\circ} 45^{\prime} \mathrm{W}$ (S. Stouge, pers. comm. 1972).

In an unnamed valley between Gurreholm Bjerge (Point 1330) and Schuchert Flod, above the Posidonia Shales, there occur yellowish arkosic sandstones with small spheroidal cementation concretions (about $20 \mathrm{~m}$ ) followed by a 1 to $2 \mathrm{~m}$ thick layer of medium to coarse conglomerate with generally well rounded pebbles of quartz, quartzitic sandstone and limestone. The conglomerate contains large productids (Horridonia). For mapping purposes this conglomerate may be considered as the top of the Foldvik Creek Formation in this area. 
The boundary between the Permian Foldvik Creek Formation and the Triassic Wordie Creek Formation is easily recognisable only where erosion before Triassic sedimentation was considerable. The lowermost Triassic (martini to commune Zone, the triviale Zone here missing) consists in this case of ammonite-bearing green or grey shales (fig. 7) as around Calamitesdal on Wegener Halvø; or of green siltstone-sandstone with ammonites, pelecypods and Bellerophon, followed by dark shales with carbonate concretions containing ammonites and fishes, as south of Paradigmabjerg on the same peninsula. Towards the central part of the basin, however, the boundary is more difficult to define in the field, as sandstones with probably reworked Permian fossils and Permian limestone fragments, and without Triassic ammonites, underlie the green and grey ammonite-bearing shales. For mapping, these sandstones were considered to belong to the Wordie Creek Formation which may therefore also include beds of Upper Permian age.

On Depot $\emptyset$, the boundary between the arenaceous Permian limestones and the few metres of dark shales with Triassic ammonites is covered by scree. On the north tip of Nordenskiöld Bjerg, the contact is tectonic. Triassic ammonites were collected at both localities.

On the west side of the basin a section was measured in the southernmost outcrop of the Permian east of Schuchert Flod (fig. 5, x; fig. 7). At this locality Cyclolobus-bearing silty shales of the Martinia Limestone Member are overlain by very similar beds with a horizon of regular, lens-shaped calcareous concretions containing early Triassic fishes. The highest specimen of Cyclolobus was found about $4 \mathrm{~m}$ below the fish horizon. The most remarkable lithological features of the layers between these two levels are four very thin clay horizons occurring at different levels down to $1.4 \mathrm{~m}$ below the fish horizon. Otherwise no obvious changes in lithology have been observed in this critical part of the sequence. Similar yellow-weathering intercalations of bluish clay occur also above the fish horizon; here the shales become slightly more calcareous and contain thin banks of calcareous sandstone in which the Triassic pelecypod Claraia stachei was found. In the solifluction scree immediately above the outcrop, irregular, lens-shaped calcareous concretions with well preserved ammonites belonging to the upper Glyptophiceras beds (maritini Zone) of the Triassic Wordie Creek Formation have been collected. Thus in this particular locality the lower boundary of this formation may tentatively be defined by the beginning of irregular and, later, intermittent sedimentation. This is revealed by the clay horizons, which do not appear to be paraconformities concealing important hiati caused by erosive processes. The possibility of paraconformities is more likely in the localities farther to the north, where the unfossiliferous layers between the highest Permian and the lowest Triassic fossil horizons become thicker and coarser grained clastics, often including conglomeratic intercalations. 
The ages of the top of the Foldvik Creek Formation and the base of the Wordie Creek Formation vary (Grasmück \& Trümpy, 1969, p. 37). The hiatus is smallest in the central and south-western part of the $c .70 \mathrm{~km}$ broad basin and increases towards north, east and south-east, where younger Triassic sediments of the Pingo Dal Formation overlie the Caledonian crystalline in Klitdal. Here, immediately west of Storefjord, at the contact of the Lower Triassic arkoses of the Klitdal Member with weathered Caledonian granite, small fragments of white limestone have been found which resemble the Permian limestones. They are possible evidence of the southern extension of the Upper Permian basin.

\section{Mesozoic}

\section{General}

The Mesozoic sediments mapped in 1971 are the same lithostratigraphic units as those dealt with in the previous years of GGU's Scoresby Sund expeditions. They are, however, redefined and formalised and new lithological units are proposed for the Triassic by Perch-Nielsen et al. (in prep.) and for the Jurassic and Cretaceous by Surlyk et al. (in press). The Triassic units are shown in table 2 while the Jurassic and Cretaceous units can be found in Surlyk \& Birkelund (this report) . Only new localities and observations are reported here.

\section{Wordie Creek Formation}

On Wegener Halvø special attention was given to the distribution of coarser clastic intercalations in the form of yellowish to pink arkoses and conglomerate layers in the Wordie Creek Formation, which otherwise consists mainly of greenish silty shales and fine-grained sandstones. They show a transport direction from the west or from the north-east, are a few to $20 \mathrm{~m}$ thick, and can only locally be used as correlation horizons. Their correlation from the outcrops in the graben area to the profiles west of it seems questionable. Thin layers comparable to the "pseudotillite" described by Grasmück \& Trümpy (1969) from the mouth of Fleming Fjord were found to occur also $12 \mathrm{~km}$ farther to the north-east. Triassic ammonites, fishes (Bobasatrania sp.), pelecypods, asteroids and algae were collected in the Wordie Creek Formation. Brachiopods and bryozoans occurring in the lowermost sandstones, and thin intercalations in the lower part of the Wordie Creek Formation, are considered to be reworked from the underlying Upper Permian.

On the west side of the basin the Wordie Creek Formation is represented mainly by green-grey, in the upper part also purplish grey to brown-grey, well bedded, platy sandstones and silty shales with numerous sedimentary features indicating 
Table 2. Age and lithological subdivision of the Triassic Scoresby Land Group

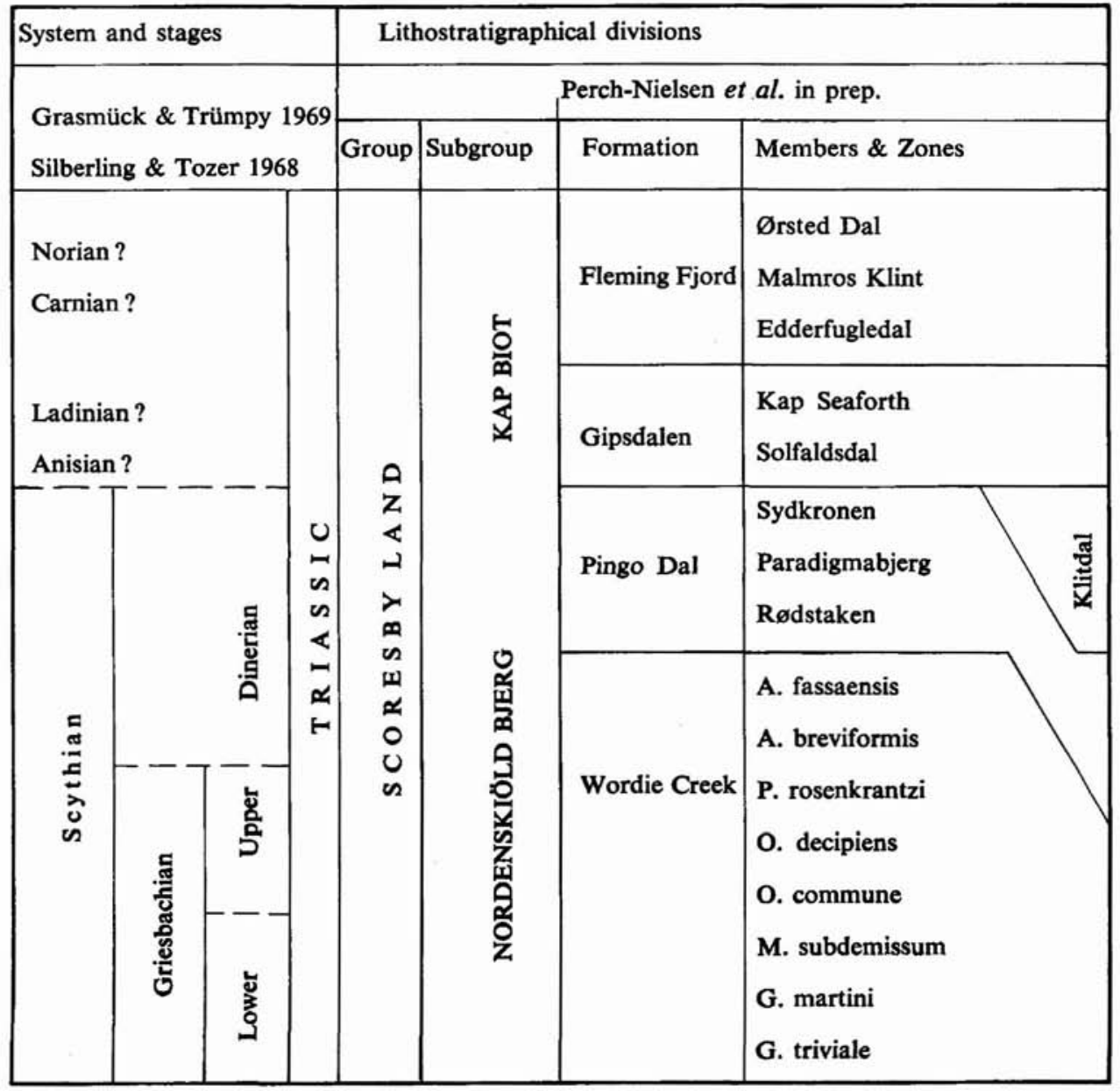

deposition in a shallow marine environment. Massive conglomerates, sometimes containing pebbles of Permian limestone, and arkosic sandstones occur especially in the lowermost part. They divide the martini and subdemissum Zones in the southern part of Gurreholm Bjerge while, farther north, replacing the martini Zone. In the southern and central part of Gurreholm Bjerge, the Wordie Creek Formation is topped by a thin algal limestone reef up to $3 \mathrm{~m}$ thick. It has locally been eroded and occurs as boulders in the basal conglomerate of the overlying Pingo Dal Formation. Northwards the reef grades into white, coarse-grained calcareous sandstones with small pelecypods (Myalina, Anodontophora), paraconformably overlain by typical Rødstaken Member sandstones. North of Pingo Dal the upper boundary is transitional, indicating partial synchroneity of the uppermost 

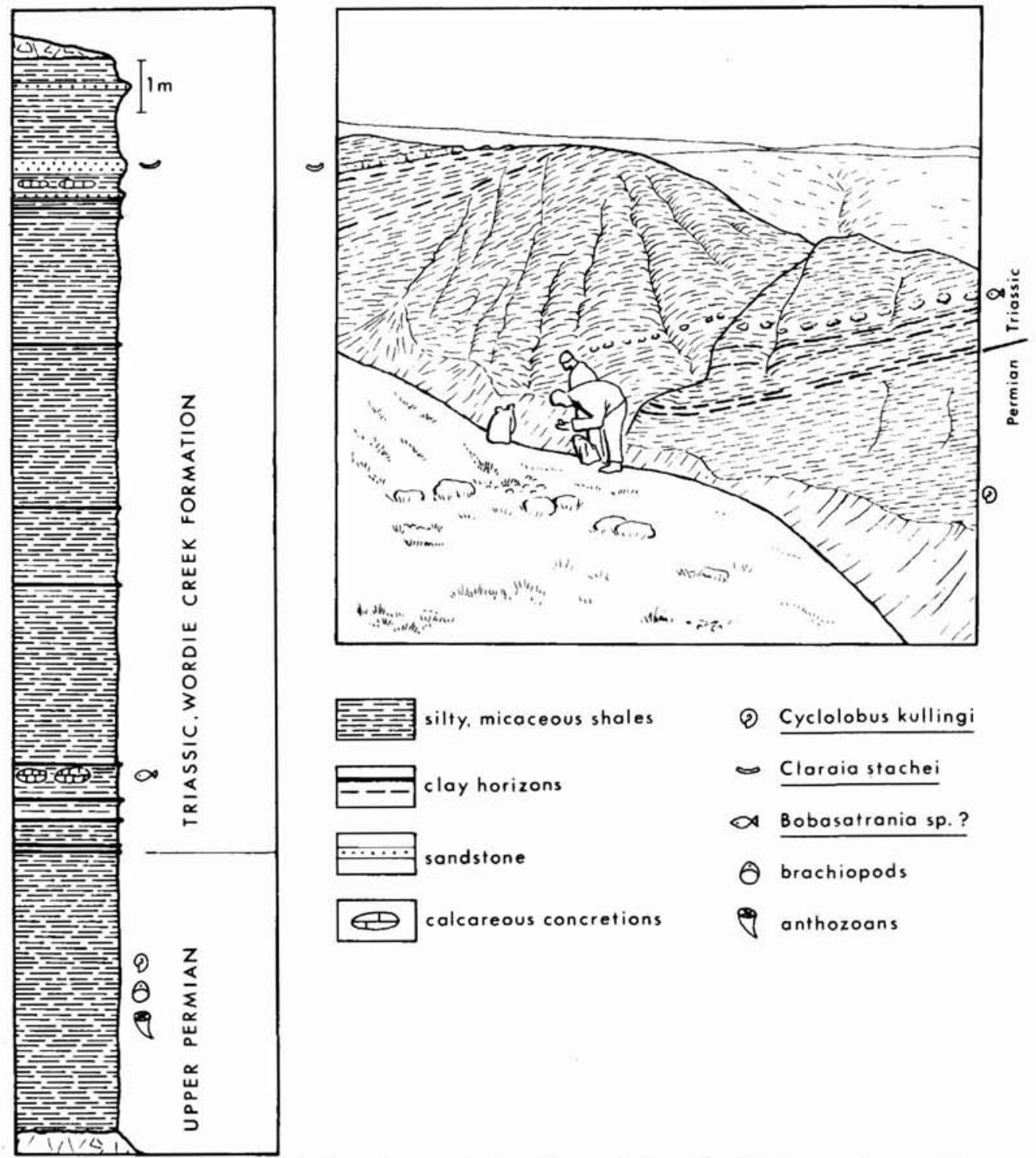

(2) Cyclolobus kullingi

$\rightarrow$ Claraia stachei

$\propto$ Bobasatrania sp.?

Q brachiopods

anthozoans

Fig. 8. The Permian-Triassic boundary at the locality marked on fig. 5. From a photograph.

Wordie Creek Formation (Anadontophora beds) and the lowermost Pingo Dal Formation (Rødstaken Member). The subdemissum and commune Zones have yielded well preserved rich faunas with ammonites over the whole area, while the martini Zone is fossiliferous only in the southernmost part of Gurreholm Bjerge. The lowermost zone, the triviale Zone, has not been identified so far by index fossils. It might be represented by the fish-horizon in the locality shown in fig. 8 . 
The fishes collected include Bobasatrania sp., Birgeria sp. and Boreosomus sp. The fossils collected in the higher parts of the formation, mainly pelecypods, but also gastropods and ammonites, are not sufficiently well preserved for clear identification of the decipiens and rosenkrantzi Zones.

Arkose and arkosic conglomerate intercalations with Upper Permian limestone pebbles occur 5 to $20 \mathrm{~m}$ thick in the area east of Schuchert Flod, and in upper Gipsdalen close to the boundary of the Wordie Creek and the Pingo Dal Formations. They may be used for local correlation purposes.

\section{Pingo Dal Formation}

In the Pingo Dal Formation, four members are distinguished. The Klitdal Member contains the pink arkosic conglomerates to breccia and coarse pink arkoses deposited along the east border of the basin, from Klitdal in the south to Nordenskiöld Bjerg in the north.

The three other members are typically developed in Pingo Dal from where they extend southwards through the central to the southern part of Gurreholm Bjerge. Northwards they are found in eastern Werner Bjerge, in Kolledalen and in the Mesters Vig region. The Rødstaken Member overlies the Wordie Creek Formation paraconformably with or without a basal conglomerate in the area south of Pingo $\mathrm{Dal}$, but conformably and with transitional interbedding of the characteristic lithologies to the north of Pingo Dal. It is characterised by dark red, purple to brown, fine-grained, often cross-bedded, platy sandstones which are normally unfossiliferous, but show sedimentary structures such as parting lineation, flow marks etc. indicating a south-western source area. In Gurreholm Bjerge the upper boundary of the Rødstaken Member is sharp, marked by light-coloured conglomeratic arkoses and sandstones containing trace fossils and intercalations of algal limestones, representing a local facies of the basal part of the Paradigmabjerg Member. North of Pingo Dal a transitional change in sedimentation is also observed at the upper boundary of the Rødstaken Member. Its upper part becomes coarser grained with intercalations of arkoses and often shows torrential bedding. Massive or banked, cross-bedded, pink, often conglomeratic arkoses and coarse sandstones with local intercalations of silty layers, often showing mudcracks, are typical for the Paradigmabjerg Member. The quantity and size of the pebbles in the conglomerates rapidly decreases from south-west to north-east. The pebbles are fairly to well rounded and often broken, mainly comprising granites and quartzites, but also yellow dolomites. In the lower part of Pingo Dal and on the east slope of Gipsdalen the coarse arkoses grade into dark red, fine-grained often cross-bedded, thinly banked to platy sandstones with intercalations of light-coloured arkoses and dark red or variegated silty shales representing the Sydkronen Member. In the muddy layers trace fossils are common; thin intercalations of algal limestones occur 
Table 3. Palaeozoic and Triassic sediments in northern Jameson Land and Scoresby Land, showing lithology, sedimentary structures and occurrence of fossils and trace fossils

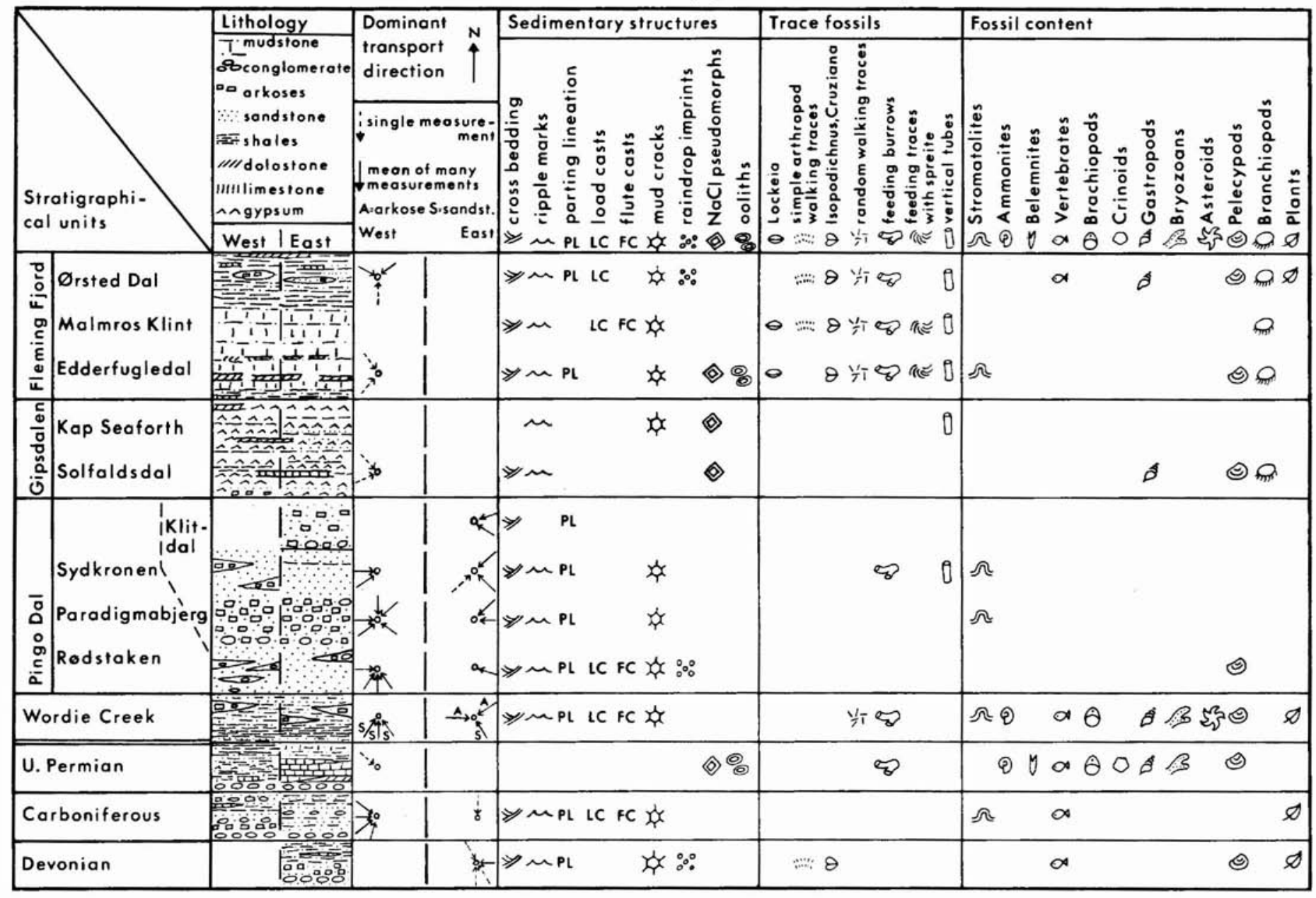


locally. The upper limit of the Pingo Dal Formation is placed at the appearance of evaporites.

For the Rødstaken Member thicknesses of 200-300 m have been measured; for the Paradigmabjerg Member, due to the incompleteness of the sections, only a minimum value of $c .500 \mathrm{~m}$ can be given for the area south of Pingo Dal, whereas north of Gipsdalen it seems to be considerably thinner, c. $300 \mathrm{~m}$. For the Sydkronen Member a maximum thickness of about $200 \mathrm{~m}$ has been observed on the north slope of Gurreholm Bjerge.

On the east side of the basin, on Wegener Halvø, red, cross-bedded sandstones and green or variegated sandstone-shale beds alternate at the base of the Rødstaken Member. The lower boundary of the member that overlies the Wordie Creek Formation is placed where red, cross-bedded sandstones decidedly predominate over variegated shale-sandstone beds. Arkosic intercalations of similar type, as known from the Wordie Creek Formation and the Paradigmabjerg Member, grow more and more frequent towards the top of the Rødstaken Member, which here also contains pelecypods. The Paradigmabjerg Member consists predominantly of pink arkoses and arkosic sandstones with subordinate conglomerates. Granites dominate the varied pebble assemblage. Large-scale cross-bedding indicates transport directions generally from the borders of the sedimentary basin towards its centre (table 3). The Sydkronen Member consists predominantly of red crossbedded sandstones with subordinate arkose and shale. Outcrops mapped as "Paradigma Member" by Grasmück \& Trümpy, 1969 and lying north of Fleming Fjord belong to this member.

\section{Gipsdalen Formation}

The evaporite beds in the Middle Triassic Gipsdalen Formation are divided into two members: the Solfaldsdal Member, generally reddish brown, and the overlying Kap Seaforth Member with predominantly grey coloured layers. The distribution of the marine Myalina limestone and/or similar calcareous intercalations in the Solfaldsdal Member was found to be wider than known previously. It occurs from the Kap Biot area in the north to Gipsdalen in the west, and south of Passagen to the south-east. It is only a few metres thick and more or less arenaceous, sometimes bituminous. The distribution of the Gipsdalen Formation along Carlsberg Fjord and in Klitdal is shown in map 3 (Surlyk \& Birkelund, this report).

In Gurreholm Bjerge, except on the north slope, and in Werner Bjerge, the Gipsdalen Formation rests on the arkoses of the Paradigmabjerg Member. In the westernmost part of the basin the evaporites are replaced by banked, weakly gypsum-cemented arkoses and yellow to pink, muddy sandstones weathering white with silty intercalations. On a ridge north of Gipsdalen a thick bank of grey dolomite with red jasper was found at the boundary of dark red, cross-bedded 
conglomerates of the Paradigmabjerg Member and light-coloured, banked, conglomeratic arkoses, which are considered as an entirely clastic equivalent of the Gipsdalen Formation. Jasper was found in a similar stratigraphical position south of Nathorst Fjord on the eastern side of the basin. Thin lenses of dark grey, unfossiliferous limestone in red and brown sandy and silty layers within the evaporites, representing probably the Myalina limestone, have also been observed south of Gurreholm Bjerge.

In southern Klitdal the Solfaldsdal Member wedges out completely and the Kap Seaforth Member comes directly into contact with the Klitdal Member.

\section{Fleming Fiord Formation}

The three members of the Fleming Fjord Formation are represented with varying thickness over the whole area of distribution of the formation, except in southern Klitdal where the lower two members wedge out. Generally the Edderfugledal Member is thickest in the north-eastern area and thins towards the south and west. Stromatolitic layers as well as oolitic layers occur in this member, also decreasing in abundance and thickness to the west. Likewise the red-brown mudstones of the Malmros Klint Member thin towards west. The overlying Ørsted Dal Member shows locally different successions of mudstones, sandstones and arkoses with conglomeratic layers. The dolomitic layers at the top of the member are well developed along the western and eastern borders of the basin south to southern Carlsberg Fjord, but are missing in Klitdal. Vertebrate remains (?Gyrolepis and fragments of reptile bones) and poorly preserved gastropods were found in the Ørsted Dal Member.

In southern Klitdal, the Ørsted Dal Member directly overlies the Klitdal Member. The Malmros Klint and Ørsted Dal Members are well exposed along the west side of Carlsberg Fjord. These exposures yielded well preserved and rich assemblages of trace fossils. The assemblages are different in the two members and indicate a freshwater origin for the Ørsted Dal Member, while possibly a few brief marine incursions may have affected the lower part of the Malmros Klint Member. A bed containing gymnosperm remains was found in the upper part of the Ørsted Dal Member.

On the west side of the basin the distribution area is practically the same for all three members of the Fleming Fjord Formation. To the west it is limited by postsedimentary faults and thus does not occur west of Gipsdalen. Generally the lower two members are thickest in the central part of the northern area, around lower Ørsted Dal. They thin westward and southward and grade into slightly more sandy facies. Also the stromatolitic and oolitic layers in the green and variegated siltstones and yellowish sandstones of the Edderfugledal Member wedge out in the same directions to be replaced by increasingly irregular nodules of algal limestones. The 
massive red mudstones of the Malmros Klint Member forming high and steep cliffs in the north are less cemented in the south-west where they are poorly exposed in gentle slopes.

In the distribution area of the Ørsted Dal Member, landslips and slumps of varying extension are frequent. This member is here composed of green and red arkosic sandstones, red mudstones and variegated nodular clays in close alternation. The arkosic sandstones contain vertebrate remains: a stegocephalian bone and plesiosaur tooth were collected. Towards the top an important change in sedimentation is indicated by the occurrence of banked dolomites and limestones containing vertebrate remains and poorly preserved gastropods. These layers also thin westward in Gurreholm Bjerge and are poorly exposed.

\section{Kap Stewart Formation}

Coarse light and fine-grained grey to greenish, continental sandstones and dark shales were found in the Kap Stewart Formation. No well preserved plant fossils were found in this formation although they are known to occur in southern Jameson Land. However, root-horizons were observed. In the northernmost area sandstones similar to those of the overlying marine Neill Klinter Formation occur as intercalations within the Kap Stewart Formation (marine ingression?) thus rendering the mapping more difficult in this poorly exposed and tectonically disturbed area. In the lowermost and uppermost dark shales, vertebrate remains (?Gyrolepis) were found south of Passagen and south of Fleming Fjord.

In the western part of the distribution area, poorly cemented and fairly to well sorted, white to yellow and grey, sometimes conglomeratic, quartzitic sandstones occur. They are interbedded with dark shales and minor coal seams containing plant remains and trace fossils, and these constitute the east slopes of Gurreholm Bjerge and the hills south of them. Fragments of fossil fishes (?Gyrolepis) were found in silty calcareous concretions near the top of the formation east of Gipsdalen and south of Gurreholm Bjerge.

A hiatus between the Fleming Fjord Formation and the Kap Stewart Formation is suggested from observations in Gipsdalen and Klitdal.

\section{Neill Klinter Formation}

A few localities with marine sandstones and shales of the Neill Klinter Formation were visited in the northern part of the area. Some Lower Jurassic ammonites and belemnites were collected from the top member of the formation together with iron oolites.

In the southern part of Scoresby Land the Neill Klinter Formation is represented 
only at two localities and with the topmost beds missing. At the south-east corner of Gurreholm Bjerge and on the northernmost top of the mountains south of them, marine fossils, mainly internal casts of pelecypods and fragments of belemnites and crustaceans, have been collected. A few fragmentary moulds of ammonites have been found at different levels of the slabby yellow to red-brown or lilac sandstones. These layers are the youngest pre-Quaternary sediments in the area north of Ørsted Dal in south Scoresby Land. In north-western Jameson Land several valleys expose Neill Klinter Formation, allowing its upper and lower boundaries to be mapped.

From south of Passagen to the south end of Carlsberg Fjord the formation was studied in some detail at many localities. The section here was measured as the type section of the middle member of the formation. In this area, thick lenses of crossbedded sandstone occur at the base of the top member of the formation and produce marked topographical features including plateaux on mountain tops. Along the west side of Klitdal three members were distinguished within the Neill Klinter Formation. A comparatively rich fauna of ammonites and belemnites was collected from the upper member.

\section{Vardekloft Formation}

Sediments of the Vardekløft Formation were studied along the eastern border of their outcrop area. Except for some Middle Jurassic ammonites and belemnites collected at two localities in the area north-west of Kap Biot in the middle member of the formation, no new observations are to be reported.

\section{Late Mesozoic and Tertiary intrusives}

Sills and dykes of various compositions and textures occur throughout the area. Sills from 1 to over $50 \mathrm{~m}$ thick outcrop less commonly east and south-east of the $\emptyset$ rsted Dal area. Dykes varying in thickness from a few centimetres to $30 \mathrm{~m}$ are especially frequent around the intrusive body and subvolcanic complexes of Werner Bjerge. Basaltic dykes trending NW-SE and cutting through the crystalline complex and its Triassic and Jurassic cover in Klitdal were sampled for absolute age determinations and palaeomagnetic studies.

\section{Mineralisations}

Minor mineralisations occur in sedimentary layers of the western part of the area as calcite and barytes geodes of up to $10 \mathrm{~cm}$ in diameter in reefy or nodular algal limestones. Veins filling post-diagenetic fractures containing calcite, and very 
seldom barytes and quartz crystals, were observed in northern Schuchert Dal. Lead mineralisation was found in the basal part of the Gypsum Member of the Foldvik Creek Formation south of Werner Bjerge. They also occur in higher stratigraphical levels of the same formation and at the base of the Wordie Creek Formation, where they are cut by fault and fracture zones.

Azurite, malachite and barytes are often found at the top of the LimestoneDolomite Member of the Foldvik Creek Formation on Wegener Halvø in small veins. They also occur sporadically in Devonian, Carboniferous and Triassic sediments, usually near faults. In the Carboniferous sandstones in Tvekegledal, chalcopyrite and rutile are present, while siderite and limonite coat joint surfaces. Hematite occurs both finely distributed and as specularite in the Pingo Dal Formation and the Carboniferous. It fills mud cracks near Kap Biot in the Malmros Klint Member.

\section{Oil source rock analysis}

20 surface samples collected during 1971 and earlier field seasons were sent to GGU's consultants Olexcon International N.V., The Hague, who undertook oil source rock analysis, micropalaeontological, microlithological and palynological studies. The few samples submitted for visual porosity determination showed the presence of porous sandstones in the Jurassic sequence. Some of the results from the source rock analysis are summarised below from Olexcon International N.V. (1972) and Stevens (pers. comm.).

Seven samples from the Upper Permian Posidonia Shale Member on Wegener Halvø gave negative results, while one sample from the same member from the Schuchert Flod area showed the chemical characteristics of an oil shale.

Eight samples from the Myalina Limestone of the Triassic Solfaldsdal Member were investigated. One of these, from the mouth of Nathorst Fjord, proved to be a good source rock, containing normal and branched paraffins. Another, from south of Passagen, would have qualified as a source rock had the nitrogen content been higher. The remaining six samples from the Kap Biot, Solfaldsdal, Wegener Halvø and northern Carlsberg Fjord areas gave negative results.

The remaining four samples from the Triassic Wordie Creek Formation on Wegener Halvø and the Jurassic Vardekløft and Hareelv Formations of Jameson Land gave negative results. 


\section{References}

Bierther, W. 1941: Vorläufige Mitteilung über die Geologie des östlichen Scoresbylandes in Nordostgrönland. Meddr Gronland 144, 6, 20 pp.

Bierther, W. in prep.: Stratigraphie der postdevonischen Sedimente des Scoresbylandes (Ostgrönland).

Bromley, R. G., Bruun-Petersen, J. \& Perch-Nielsen, K. 1970: Preliminary results of mapping in the Palaeozoic and Mesozoic sediments of Scoresby Land and Jameson Land. Rapp. Gronlands geol. Unders. 30, 17-30.

Bütler, H. 1948: Notes on the geological map of Canning Land (East Greenland). Meddr Grønland 113, 2, 97 pp.

Callomon, J. H. 1970: Geological map of Carlsberg Fjord - Fossilbjerget area. Meddr Gronland $168,4,10 \mathrm{pp}$.

Grasmück, K. \& Trümpy, R, 1969: Triassic stratigraphy and general geology of the country around Fleming Fjord (East Greenland). Meddr Gronland 168, 2, 5-71.

Kempter, E. 1961: Die jungpaläozoischen Sedimente von Süd Scoresby Land. Meddr Gronland $164,1,123$ pp.

Maync, W. 1942: Stratigraphie und Faziesverhältnisse der oberpermischen Ablagerungen Ostgrönlands. Meddr Gronland 115, 2, 128 pp.

Noe-Nygaard, A. 1934: Stratigraphical outlines of the area round Fleming Inlet (East Greenland). Meddr Gronland 103, 1,88 pp.

Olexon International N.V. 1972: Results of various analyses of surface samples from East Greenland. Olexon report to GGU.

Perch-Nielsen, K., Birkenmajer, K., Birkelund, T. \& Aellen, M. in prep.: Revision of Triassic stratigraphy of the Scoresby Land and Jameson Land region, East Greenland.

Silberling, N. J. \& Tozer, E. T. 1968: Biostratigraphic classification of the marine Triassic in North America. Spec. Pap. geol. Soc. Amer. 110, 63 pp.

Surlyk, F., Callomon, J. H., Bromley, R. \& Birkelund, T. in press: Stratigraphy of the Jurassic-Lower Cretaceous sediments of Jameson Land and Scoresby Land, East Greenland. Bull. Grønlands geol. Unders. (also Meddr Gronland).

Witzig, E. 1954: Stratigraphische und tektonische Beobachtungen in der Mesters Vig-Region (Scoresbyland, Nordostgrönland). Meddr Gronland 72, 5, 26 pp. 